\title{
Planned Duration
}

National Cancer Institute

\section{Source}

National Cancer Institute. Planned Duration. NCI Thesaurus. Code C93625.

The period of time over which the event or activity is intended to take place. 